\title{
Bitewing Dose Reduction using TWAIN
}

\author{
Branets $\mathbf{I}^{1,2}$, Minhadian $\mathrm{M}^{2}$, Patchell $\mathrm{G}^{2}$, Dauer $\mathrm{LT}^{3}$, Quinn $\mathrm{B}^{3}$, Ahn $\mathrm{T}^{4}$, Faber $\mathrm{RD}^{4}$, Colosi DC ${ }^{2}$ and \\ Goren $\mathrm{AD}^{1,2 *}$ \\ ${ }^{1}$ Department of Cariology and Comprehensive Care, New York University College of Dentistry, USA \\ ${ }^{2}$ Department of Prosthodontics and Digital Technology, SUNY Stony Brook School of Dental Medicine, USA \\ ${ }^{3}$ Department of Medical Physics, Memorial Sloan-Kettering Cancer Center, USA \\ ${ }^{4}$ Department of Orthodontics, SUNY Stony Brook School of Dental Medicine, USA
}

Submission: January 23, 2017; Published: February 03, 2016

*Corresponding author: Goren AD, Department of Cariology and Comprehensive Care, New York University College of Dentistry, USA, Email: ag153@nyu.edu

\begin{abstract}
Background: TWAIN stands for "technology without an interesting name". TWAIN is the interface standard for Windows and Mac that allows imaging hardware devices to communicate with imaging processing software. Prior to TWAIN, image acquisition devices all came with their own proprietary software, now nearly all imaging processing software today is TWAIN compliant.

Objective: To determine if using TWAIN for bitewing imaging reduces the absorbed dose and the effective dose to the patient when compared with EMAGO.

Materials and Methods: Dose measurements were obtained using Optically Stimulated Luminescent (OSL) dosimeters placed in premanufactured slots at the location of 23 head and neck anatomical structures of an anthropomorphic female CIRS phantom. A Schick direct digital sensor was placed within the phantom in a bilateral removable cutout corresponding to typical sensor placement for bitewing radiographs. Exposures were acquired using a Gendex $765(65 \mathrm{kVp}, 7 \mathrm{~mA})$ and a Gendex $770(70 \mathrm{kVp}, 7 \mathrm{~mA}) \mathrm{x}$-ray machines. The TWAIN exposures were $0.63 \mathrm{~s}$ for the 765 machine and 4 impulses for the 770 machine and the EMAGO exposures were $0.125 \mathrm{~s}$ for the 765 machine and 8 impulses for the 770 machine. All exposures were repeated 10 times. The results were divided by their respective repetition numbers to calculate average dose. The organ fractions irradiated were determined from ICRP-89 reference phantoms according to age. ICRP-103 tissue weighting factors were also applied.
\end{abstract}

Results: Overall the TWAIN software reduced the absorbed dose at $65 \mathrm{kVp}$ by $64 \%$ and at $70 \mathrm{kVp}$ by $61 \%$. When calculating the effective dose the reduction at $65 \mathrm{kVp}$ was $64 \%$ and $45 \%$ at $70 \mathrm{kVp}$.

Conclusion: Our data showed that use of the TWAIN software yielded the lowest absorbed dose and effective dose to organs of the head and neck at all exposure times for bitewing radiographs.

Keywords: Bitewing; Dose reduction; TWAIN; EMAGO; Optical stimulated luminescence

\section{Background}

TWAIN stands for "technology without an interesting name". TWAIN is the interface standard for Windows and Mac that allows imaging hardware devices to communicate with imaging processing software. Prior to TWAIN, image acquisition devices all came with their own proprietary software, now nearly all imaging software is TWAIN compliant. If one wanted to work with a scanned image in a different application, one had to save the image to a disc first, then open the application of your choice and re-open the image there. Nearly all image processing software today is TWAIN compliant. If your software supports
TWAIN, you will find an "Acquire" command in the menus or toolbar (though sometimes the command is hidden under an import in menu.

This command provides access to any TWAIN hardware devices installed on the system. Although the software appearance and capabilities for each device can vary, the TWAIN Acquire command calls up the hardware interfacing software, and places the acquired image into the image processing software, without the need for the image to first be saved to disc. So what does TWAIN really stand for? According to "The 
Free ON-Line Dictionary of Computing" [1] and substantiated by the "TWAIN Working Group's official Web site" [2] it's Not an acronym at all: The word TWAIN is from Kipling's "The Ballard of East and West" [3] "and never the twain shall meet", reflecting the difficulty, at the time, of connecting scanners and personal computers. It was up-cased to TWAIN to make it more distinctive.

This led people to believe it was an acronym, and then to a contest to come up with an expansion. None were selected, but the entry "Technology without an Interesting Name" continues to haunt the standard. According to the definition from Wikipedia: TWAIN is an applications programming Interface (API) and communication between software and digital imaging devices. Here we are using dental imaging devices. Dental radiographs are a useful and necessary tool in the diagnosis and treatment of oral diseases such as caries and oral pathologies. Intraoral radiography is still the most common radiographic technique used in dental imaging. Posterior bitewing radiographic imaging is recognized as an important dental radiographic modality. As in all dental radiographic imaging, bitewing imaging should be utilized by dentists only after reviewing the patient's health history, completing a clinical exam and after ensuring that exposure to radiation is minimized where practicable through the use of a solid quality assurance and control program.

Dentists should weigh the benefits of dental x-rays against the consequences of increasing a patient's exposure to radiation. Optically stimulated dosimetry (OSL) technology has been shown to have a 10 to $20 \%$ higher sensitivity than thermoluminescent dosimeters (TLDs) at the lower dose range [4]. The In Light OSL Nano Dot Dosimeters measure radiation exposure using Aluminum Oxide detectors. The amount of light released upon stimulation of the detector by a light emitting diode array is directly proportional to the radiation dose to which the detector has been exposed. EMAGO is a comprehensive diagnostic tool in oral and maxillofacial radiology. It is a collection of useful image management and image analysis software functions that helps to improve diagnostic image interpretation. It is a solution for managing all digital $x$-ray devices in a dental practice. It supports practically all dental x-ray systems. The features included in EMAGO are: vendor independent, import and export capabilities, optimization of images, selective templates, measuring and annotative functions, and advanced research tools.

\section{Objective}

To determine if using TWAIN for bitewing imaging reduces the absorbed dose and the effective dose to the patient when compared with EMAGO.

\section{Methods and Materials}

An adult female anthropomorphic phantom (Model 702,CIRS) representing an average woman was used for all exposures. The phantom is manufactured to ICRP 23 and ICRU 48 specifications. We utilized the head and neck sections (12 sections) (Figure 1). OSL dosimeters (NanoDot) were used to asses ten key head and neck organs (Figure 2). All bitewing exposures were performed on a Gendex 765, Gendex 770, Kodak 9000, and Sirona Orthoophos XG Plus. Histograms, (Figure 3) were made to determine equivalent images and correct exposure times. All these exposures were performed using EMAGO and TWAIN as the software. Digital panoramicscans were performed using the Kodak and Sirona machines only with TWAIN. Three exposures were taken for each protocol. Care was taken to always place the dosimeters in the same orientation for each type of exposure. Unexposed dosimeters were used as controls. The total organ dose was calculated by summing up the individual reading per location within a given organ and dividing by the number of locations. All dosimeters were read three times and background readings were subtracted from the averaged readings. Estimated organ dose and effective dose were also calculated.
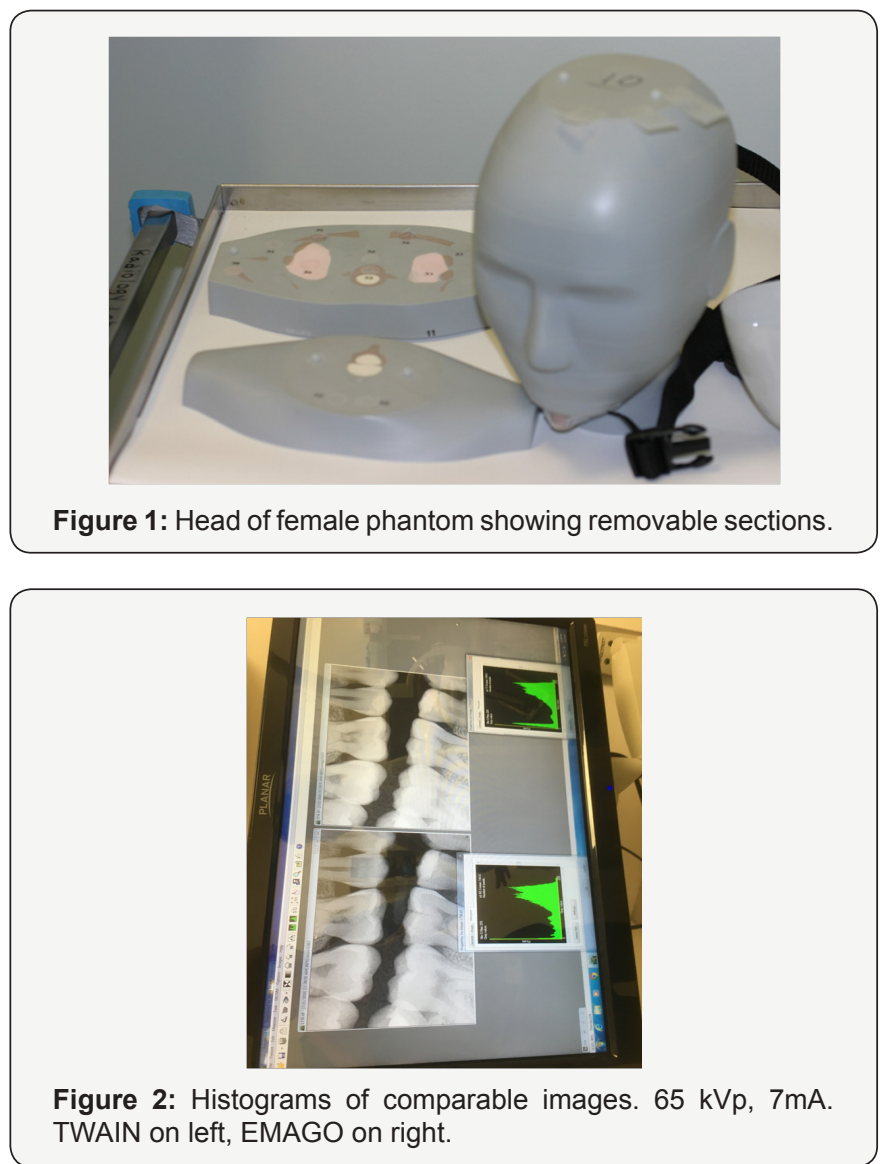

\section{Results}

Table 1 shows the results 10 exposures taken at $65 \mathrm{kVp}, 7 \mathrm{~mA}$ and 0.125 seconds using EMAGO. Table 2, the exposure results for the TWAIN 10 exposures at $65 \mathrm{kVp}, 7 \mathrm{~mA}$ and 0.63 seconds. Table 3 , shows the $64.4 \%$ dose reduction at the six organ sites using TWAIN. Table 4 shows the comparison of the Sirona and Kodak machines for the digital Pan bitewing function using TWAIN. Table 5 is for the estimated organ dose in micro-grays. Table 6 indicates the effective dose in micro-Sieverts assuming the ICRP-103 tissue weighting factors. 
Table 1: EMAGO, 10 exposures, $65 \mathrm{kVp}, 7 \mathrm{~mA}, 0.125$ second exposure for 5 organs. All exposures in net mrad.

\begin{tabular}{|c|c|}
\hline Brain & 8 \\
\hline Cranium & 3 \\
\hline C-Spine & 11 \\
\hline Eyes & 46 \\
\hline Mandible & 980 \\
\hline Thyroid & 8 \\
\hline
\end{tabular}

Table 2: TWAIN, 10 exposures, $65 \mathrm{kVp}, 7 \mathrm{~mA}, 0.63$ second exposure for 5 organs. All exposures in net mrad.

\begin{tabular}{|c|c|}
\hline Brain & 5 \\
\hline Cranium & 2 \\
\hline C-Spine & 0 \\
\hline Eyes & 29 \\
\hline Mandible & 354 \\
\hline Thyroid & 0 \\
\hline
\end{tabular}

Table 3: Absorbed dose reduction of $64.4 \%$ between TWAIN and EMAGO at $65 \mathrm{kVp}$ in net mrads.

\begin{tabular}{|c|c|c|}
\hline & TWAIN & EMAGO \\
\hline Brain & 5 & 8 \\
\hline Cranium & 2 & 3 \\
\hline C-Spine & 0 & 11 \\
\hline Eyes & 29 & 46 \\
\hline Mandible & 354 & 980 \\
\hline Thyroid & 0 & 8 \\
\hline
\end{tabular}

Table 4: Comparison of bitewing organ doses between Sirona and Kodak x-ray units.

\begin{tabular}{|c|c|c|c|c|}
\hline & Type & $\begin{array}{c}\text { Sirona } \\
\text { BW }\end{array}$ & $\begin{array}{c}\text { Sirona } \\
\text { BW }\end{array}$ & $\begin{array}{c}\text { Kodak } \\
\text { BW }\end{array}$ \\
\hline & Run & $64 \mathrm{kV} / 8 \mathrm{~mA}$ & $64 \mathrm{kV} / 8 \mathrm{~mA}$ & $\begin{array}{l}64 \mathrm{kv} / \\
8 \mathrm{~mA}\end{array}$ \\
\hline & Time & $10 \mathrm{sec}$ & $8.8 \mathrm{sec}$ & $4.8 \mathrm{sec}$ \\
\hline Measure- & Phantom & Female & Female & Female \\
\hline ments & & $\mu G y$ & $\mu G y$ & $\mu \mathrm{Gy}$ \\
\hline Brain & & 1.5 & 3.6 & 2.4 \\
\hline Calvarium & & 1.4 & 2.6 & 2.8 \\
\hline Mandible & & 72 & 77 & 89.7 \\
\hline Maxilla & & 72 & 77 & 89.7 \\
\hline C-Spine & & 10.5 & 6.3 & 4.6 \\
\hline Thyroid & & 5.5 & 3.1 & 4.1 \\
\hline Clavicle & & 5.5 & 3.1 & 4.1 \\
\hline Skin & & 10.5 & 77 & 89.7 \\
\hline Eye & & 3.8 & 4.9 & 8.3 \\
\hline
\end{tabular}


Tables 5: Estimated organ dose in micrograys from Sirona and Kodak machines

\begin{tabular}{|c|c|c|c|c|c|c|}
\hline Tissue Irradiated & Adult Fraction & Sirona Pan & $\begin{array}{c}\text { Sirona BW } 10 \\
\text { sec }\end{array}$ & $\begin{array}{c}\text { Sirona BW } 8.8 \\
\text { sec }\end{array}$ & Kodak Pan & $\begin{array}{c}\text { Kodak BW } 4.8 \\
\text { sec }\end{array}$ \\
\hline Bone Marrow & 0.123 & 0.01 & 1.1 & 1.1 & 1.1 & 1.1 \\
\hline Mandible & 0.008 & 0.0 & 0.6 & 0.6 & 0.6 & 0.7 \\
\hline Calvarium & 0.76 & 0.0 & 0.2 & 0.2 & 0.2 & 0.2 \\
\hline C-Spine & 0.039 & 0.0 & 0.4 & 0.2 & 0.3 & 0.2 \\
\hline Thyroid & 1.0 & 0.4 & 5.5 & 3.1 & 4.5 & 4.1 \\
\hline Esophages & 0.2 & 0.1 & 1.1 & 0.6 & 0.9 & 0.8 \\
\hline Skin & 0.05 & 0.0 & 0.5 & 3.9 & 5.4 & 4.5 \\
\hline Bone & 0.123 & 0.2 & 4.6 & 4.4 & 4.8 & 4.6 \\
\hline Mandible & 0.008 & 0.0 & 2.4 & 2.6 & 2.7 & 3.0 \\
\hline Calvarium & 0.076 & 0.1 & 0.4 & 0.8 & 1.0 & 0.9 \\
\hline C-Spine & 0.039 & 0.1 & 1.7 & 1.0 & 1.1 & 0.7 \\
\hline Salivary Glands & 1.0 & 2.7 & 216.0 & 231.0 & 240.0 & 269.1 \\
\hline Parotid & 1.0 & 0.9 & 72.0 & 77.0 & 80.0 & 89.7 \\
\hline Sub Man & 1.0 & 0.9 & 72.0 & 77.0 & 80.0 & 89.7 \\
\hline Sublingual & 1.0 & 0.9 & 72.0 & 77.0 & 80.0 & 89.7 \\
\hline Brain & 1.0 & 0.4 & 1.5 & 3.6 & 5.6 & 2.4 \\
\hline \multicolumn{7}{|l|}{ REST } \\
\hline Lymph Nodes & 0.05 & 0.0 & 2.0 & 2.0 & 2.1 & 2.4 \\
\hline Muscle & 0.05 & 0.0 & 2.0 & 2.0 & 2.1 & 2.4 \\
\hline $\begin{array}{c}\text { Extrathoracic } \\
\text { Airway }\end{array}$ & 1.0 & 0.5 & 26.9 & 27.8 & 29.5 & 31.8 \\
\hline Oral Mucosa & 1.0 & 0.9 & 72.0 & 77.0 & 80.0 & 89.7 \\
\hline Lens of Eye & $(\mu \mathrm{Sv})$ & 0.4 & 3.8 & 4.9 & 107.0 & 8.3 \\
\hline
\end{tabular}

Table 6: Effective dose in micro Sieverts using ICRP-103 Tissue Weighting Factors.

\begin{tabular}{|c|c|c|c|c|c|}
\hline & Sirona Pan & Sirona BW 10 sec & Sirona BW 8.8 sec & Kodak Pan & Kodak BW 4.8 sec \\
\hline Lens of Eye & 0.4 & 3.8 & 4.9 & 8.3 \\
\hline Effective Dose & 0.1 & 5.7 & 6.0 & 6.3 \\
\hline
\end{tabular}

\section{Discussion and Conclusion}

The organ dose and effective dose are within the limits published for dental cone beam radiation. However during our studies the Kodak 9000 emitted the higher dose to the patient than the Sirona Ortho Plus when Panorex Bitewing imaging was obtained using TWAIN. We could not obtain a comparison with EMAGO for the two machines since EMAGO was not the operational system for these machines. For Bitewing imaging the use of TWAIN as the operating system verses EMAGO reduced the radiation exposure to the patient while obtaining

\section{References}

1. TWAIN-wikipedia.

2. www.twain.org/contactus.html.

3. Ballard of East and West, Rudyard Kipling (1889), Edmund Clarence Stedman, ed. 1895.

4. Branets I, Branets L, Colosi DC, Quinn B, Dauer LT, et al. (2014) Optical Stimulated Luminescent Dosimetry and Thermo luminescent Dosimetry: An Overall Perspective. Research 1: 720. 
This work is licensed under Creative Commons Attribution 4.0 Licens
Your next submission with Juniper Publishers will reach you the below assets

- Quality Editorial service

- Swift Peer Review

- Reprints availability

- E-prints Service

- Manuscript Podcast for convenient understanding

- Global attainment for your research

- Manuscript accessibility in different formats ( Pdf, E-pub, Full Text, Audio)

- Unceasing customer service

Track the below URL for one-step submission https://juniperpublishers.com/online-submission.php 